\title{
PEMBEKALAN KETERAMPILAN LAS DI PONDOK PESANTREN AL IKHSAN II, BENTOK, BATI-BATI
}

\author{
Muhammad Firman, Muhammad Saukani, Saifullah Arief, \\ Mujiburrahman, Heri Irawan \\ Program Studi Teknik Mesin, Fakultas Teknik \\ Universitas Islam Kalimantan Muhammad Arsyad Al Banjari Banjarmasin \\ Email : firmanuniska99@gmail.com
}

\begin{abstract}
ABSTRAK
Pondok Pesantren Al-Ikhsan II adalah Pondok Pesantren yang memiliki program pembelajaran Tahfidzh Al-Quran dan Program Alim serta program umum kurikulum kementerian agama. Tidak seperti pondok pesantren pada umumnya, di pondok pesantren ini, santri tidak diwajibkan untuk mengikuti Pendidikan dengan kurikulum kementerian agama, semua keputusan diserahkan kepada santri dan orang tuanya. Sebagai upaya penikatan life skill santri, pihak pondok telah memiliki peralatan las listrik dan alat potong yang cukup lengkap, namun belum ada tenaga terampil untuk menggunakan dan melatih para santri, maka program ini belum terlaksana. Melalui Program Pemberdayaan Masyarakat inilah, permasalahan peningkatan life skill dalam bidang pengelasan akan diberikan. Bentuk kegiatan yang akan dilaksanakan berupa penyampaian materi K3, Teknik pengelasan dan pemotongan. Selanjutnya pendampingan praktik pengelasan dan pemotongan dilakukan hingga santri mampu menghasilkan produk. Hasil program ini akan dipublikasikan pada jurnal MEDITEG Politeknik Negeri Tanah Laut atau Jurnal Pengabdian Masyarakat AL IKHLAS Universitas Islam Kalimantan (UNISKA) Muhammad Arsyad Al Banjari.
\end{abstract}

Kata Kunci:Life Skill, Las, K3, Santri.

\section{PENDAHULUAN}

Pondok Pesantren Al-Ikhsan II beralamat di Jl. Mistar Cokrokusumo, Desa Bentok Kampung, Kecamatan Bati-bati, Kabupaten Tanah Laut, Kalimantan Selatan. Pondok ini berdiri di atas tanah seluas $16 \mathrm{Ha}$. Jumlah santri yang terdaftar sebanyak 462 orang, terdiri dari 230 Putra, dan 232 Putri. Sebaran santri yang belajar di Pondok Persantren ini tidak hanya santri-santri dari Kalimantan namun juga dari luar pulau Kalimantan(Saukani and Arifin,
2019). Secara tersirat UU Sisdiknas No.

20 Tahun 2003 menyebutkan bahwa potensi peserta didik dapat dikembangkan melalui Pendidikan agar berani menghadapi problema kehidupan tanpa merasa tertekan, serta senang mengembangkan diri menjadi manusia unggul(Rahim, 2016). Pengembangan Pendidikan tersebut dapat dimaknai dalam perwujudan peningkatan life skill sehingga mampu menjadi modal tambahan santri setelah lulus(Hidayat, 2016; Noor, 2015). 
Pondok pesantren Al-Ikhsan memiliki peralatan las listrik dan alat potong yang cukup lengkap. Namun keadaan peralatan las tersebut tersimpan rapi di dalam Gudang, dikarenakan belum ada tenaga terampil untuk menggunakannya. Selain itu sebagai upaya peningkatan keterampilan santri juga belum bila dilaksanakan, karena belum adanya instruktur yang dapat mendidik santri baik secara teori maupun praktek. Dengan adanya Program Pemberdayaan Masyarakat inilah yang akan dijadikan kegiatan yang akan memberdayakan peralatan yang dimiliki oleh pondok pesantren untuk meningkatkan skill para santri khususnya santri dewasa baik secara pengetahuan hingga tatanan praktik.

Permasalahan Mitra berdasarkan analisis situasi yang diuraikan adalah karena tidak diberikannya pendidikan formal setara SMP dan SMA kepada seluruh santri, peralatan las dan potong yang dimiliki oleh Pondok Pesantren belum termanfaatkan untuk peningkatan life skill santri akibat belum adanya instruktur yang dapat memberikan pelatihan kepada mereka.

Dari hasil diskusi dengan pihak pondok pesantren, maka permasalahan prioritas yang akan diselesaikan oleh tim pelaksana PPM UNISKA adalah pemberian pembekalan teori dan praktik pengelasan kepada santri sebagai upaya pemanfaatan fasilitas dan peningkatan life skill para santri.

$$
\text { Sedangkan solusi yang }
$$
ditawarkan oleh tim PPM UNISKA untuk menyelesaikan permasalahan prioritas yang telah disepakati bersama mitra adalah dengan memberikan pembekalan secara teoritis beberapa pengetahuan terkait Kesehatan dan Keselamatan Kerja (K3) dan pengelasan kepada santri. Serta memberikan pelatihan praktik las dan potong kepada santri hingga dihasilkan produk yang bermanfaat untuk pondok pesantren.

Target luaran akan dicapai dari Program Pemberdayaan Masyarakat ini adalah mampu menyelesaikan masalahmasalah prioritas yang telah disepakati antara pengusul dengan mitra. Adapun target capaian dirincikan berikut ini: Kemanfaatan Peralatan Las dan Potong untuk peningkatan life skill santri, target capainnya 50\%, Peningkatan Pengetahuan K3, teknik las dan Teknik potong, target capaiannya $70 \%$, Peningkatan keterampilan las dan potong, target capainnya 50\%, dan Luaran wajibnya adalah Publikasi ilmiah pada jurnal ber ISSN. 


\section{METODE KEGIATAN}

Metode yang digunakan untuk tercapainya program ini adalah: Metode ceramah, Metode Tanya jawab (diskusi), Metode partisipatif dan Simulasi atau praktek langsung Teknik pengelasan serta pemotongan material. Waktu pelaksanaan selama 4 jam dari jam 9.30 pagi sampai jam 12.30 siang, selama 3 hari.

Khalayak sasaran dalam program ini adalah Santri Pondok Pesantren Putra Al Ikhsan II, Desa Bentok Kampung, Kecamatan Bati-bati, Tanah Laut.

\section{HASIL PELAKSANAAN KEGIATAN}

Pelaksanaan kegiatan yang dilakukan adalah pada awal kegiatan tim pengusul melakukan koordinasi dengan pimpinan Pondok pesantren Al Ikhlas II, membahas tentang program kerja yang akan dilaksanakan untuk sebagai upaya peningkatan keterampilan santri baik secara pengetahuan hingga tatanan praktik, juga untuk memberdayakan peralatan yang dimiliki oleh pondok pesantren.

Pelaksanaan pengabdian yang dilaksanakan selama tiga hari yaitu pada tanggal

1 - 3 Maret 2021, pelaksanaan dari jam
9.30 pagi sampai jam 12.30 siang. Jumlah santri yang ikut pelatihan sebanyak 17 orang karena waktu mereka agak longgar sebab sudah menyetorkan hapalan kepada ustad sehingga mendapatkan ijin untuk mengikuti kegiatan. Kegiatan yang dilaksanakan berjalan dengan lancar dan mendapat respon yang sangat baik dari para santri dan ustad yang ditunjukkan dengan memberikan ijin kepada para santri untuk menambah pengetahuan dan keterampilan mereka dalam Teknik pemotongan serta pengelasan logam yang menurut standar Kesehatan dan Keselamatan Kerja (K3) dan juga banyaknya para santri bertanya serta juga mencoba mempraktekkan secara langsung bagaimana cara mengelas yang benar dan menghasilkan hasil pengelasan yang baik. Dari pengamatan kami selama pelaksanaan teori dan praktek rata-rata $70 \%$ sudah mampu menguasai Teknik pengelasan dengan baik dan benar dengan hasil pelatihan seperti pada gambar.

Kegiatan pengelasan yang dilakukan adalah membuat tempat sampah untuk pondok pesantren putri. 


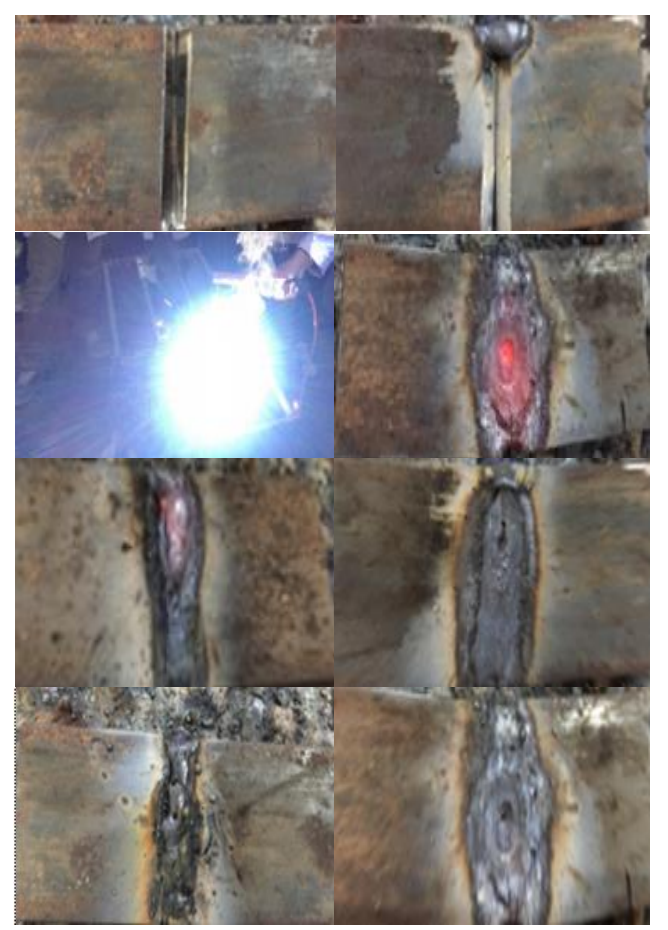

Pre Test dan Post Test Hasil Pengelasan

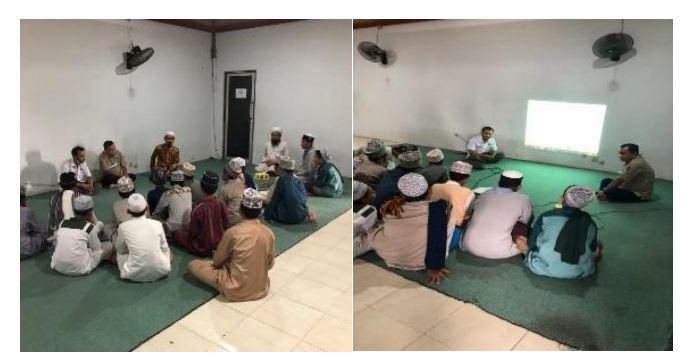

Proses Pembekalan

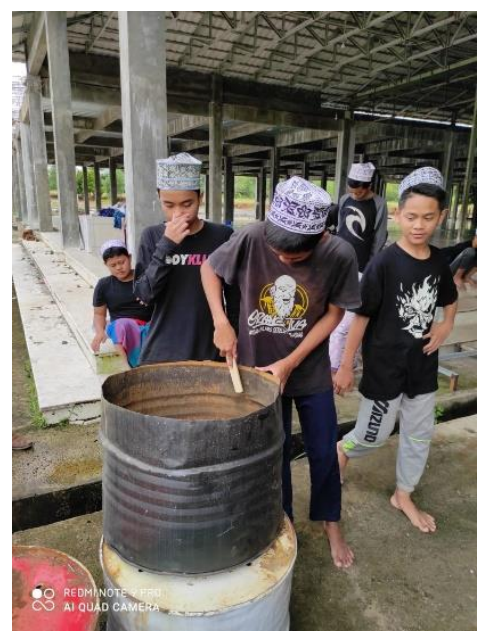

Proses Pembersihan

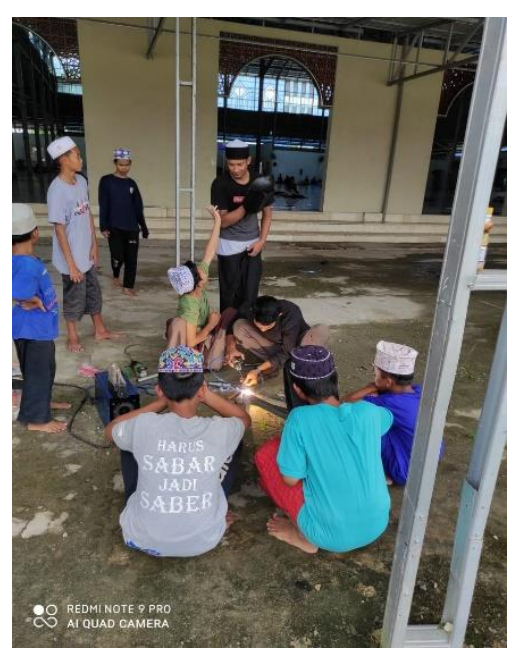

Proses Pengelasan

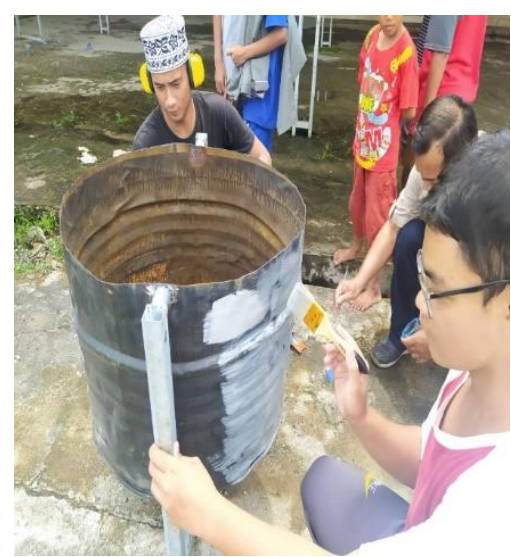

Proses Pengecatan

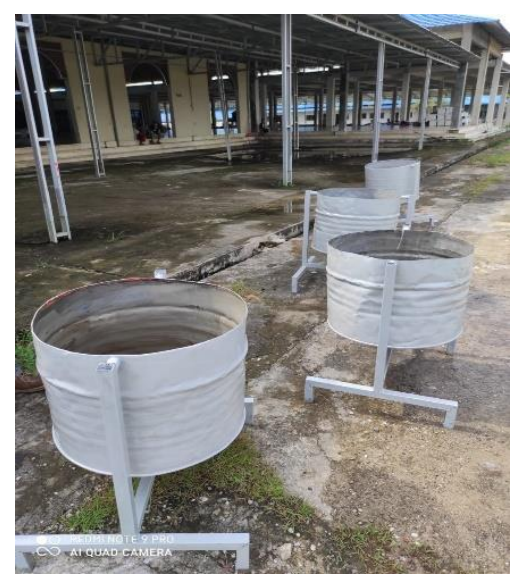

Bak Sampah Hasil dari Pelatihan 


\section{KESIMPULAN}

Dari pelaksanaan kegiatan pengabdian di Pondok Pesantren Al Ihklas II Bentok dapat disimpulkan sebagai berikut:

a. Sambutan pengelola Pondok Pesantren yang cukup baik sangat membantu kelancaran pelaksanaan pengabdian.

b. Para santri yang mengikuti pelatihan sangat antusias, yaitu dengan bersemangatnya para santri untuk mencoba mengelas dan melakukan pemotongan material dengan benar.

c. Dari hasil pre test dan pos test yang tim lakukan, terjadi peningkatan pengetahuan dan keterampilan pengelasan serta pemotongan.

d. Hasil pengelasan yang dilakukan sudah cukup baik.

Saran, perlu diadakan kembali pelatihan yang serupa buat menambah wawasan dan ketempilan para santri, untuk bekal nanti mereka kalau sudah terjun di tengah masyarakat.

\section{DAFTAR PUSTAKA}

Firman, M., Mujiburrahman., Irawan, H., Irfansyah, M., Peningkatan
Keterampilan Pengelasan Bagi Masyrakat Di Desa Muara Halayung Kecamatan Beruntung Baru Kabupaten Banjar, Jurnal Pengabdian AlIkhlas, Volume 6 Nomor 2, Desember 2020, 164 - 169.

https://ojs.uniskabjm.ac.id/index.php/AIJP/artic le/view/3892/2526

Hidayat, D., 2016. Dampak Pelatihan Keterampilan Hidup (Life Skills) Montir Otomotif Terhadap Kesempatan Kerja dan Pendapatan Warga Belajar. J. Ilm. VISI PPTK PAUDNI 11,18 .

Noor, A.H., 2015. Pendidikan

Kecakapan Hidup (Life Skill) di Pondok Pesantren dalam Meningkatkan Kemandirian Santri. Empower. J. Ilm. Program Studi Pendidik. Luar Sekolah. 4, 1-31. https://doi.org/10.22460/empo werment.v4i1p1-31.553

Rahim, A., 2016. Pendidikan Berbasis Life Skill di PondokPesantren. AL-RIWAYAH J. KEPENDIDIKAN 8, 171-194.

Saukani, M., Arifin, J., 2019.

TransformasiBudaya Buang SampahTerpilah di PondokPesantren Al IkhsanIi, Bentok. J. Pengabdi. Kpd. Masy. MEDITEG 4, 27-32. https://doi.org/10.34128/medit eg.v4i1.39 